\title{
Field and Laboratory Study of Kotal-e Dokhtar 1 and 2 Stone Quarries and Sassanid Paving Road in Kazerun County in South of Iran
}

\author{
Mohammad Hossein Rezaei ${ }^{1, *}$, Kourosh Ahmadi ${ }^{2}$ \\ ${ }^{1}$ Faculty of Humanities, Department of Archaeology in University of Neyshabur, Neyshabur, Iran \\ ${ }^{2}$ Faculty of Humanities, Archaeology, Islamic Azad University of Kazerun, Kazerun, Iran
}

Email address:

mohammad.1561@yahoo.com (M. H. Rezaei)

\section{To cite this article:}

Mohammad Hossein Rezaei, Kourosh Ahmadi. Field and Laboratory Study of Kotal-e Dokhtar 1 and 2 Stone Quarries and Sassanid Paving Road in Kazerun County in South of Iran. International Journal of Archaeology. Vol. 4, No. 1, 2016, pp. 5-10.

doi: $10.11648 /$ j.ija.20160401.12

\begin{abstract}
Kazerun County is located west of Fars Province at an altitude of 732 meters above sea level with $29^{\circ} 37^{\prime} 10^{\prime \prime} \mathrm{N}$ $51^{\circ} 39^{\prime} 15^{\prime \prime}$ E coordinates. Kazerun Plain is located in a syncline, the majority of which is covered by Quaternary sediments. In the wake of recent archaeological studies in east of Kazerun County, two stone quarries as well as a Paving Road related to Sassanid period were discovered in the mountainous region known as Kotal-e Dokhtar. One of the quarries is located upstream of the ancient road and the other on hillside not far from it. In this study, the Paving Road and detected Kotal-e Dokhtar 1 and 2 quarries were first investigated and sampled and were then subject to a number of experiments. Microscopic analysis of thin sections and XRF were among the methods used for assessment. Experiments showed that the samples of Kotal-e Dokhtar 1 and 2 quarries had a similar composition and structure with some stones used to construct the Paving Road. The Paving Road is likely constructed in Sassanid period due to the following reasons: Importance of this area in Sassanid period and the existence of Sassanid city of Bishapur in this county, and Similarity of the experiment results on the stones of Bishapur monuments and detected stone quarries in this area, and Presence of other Sassanid sites and structures such as square dome of this period in a distance of 35 kilometers from this road and Kotal-e Dokhtar 1 and 2 stone quarries.
\end{abstract}

Keywords: Field Study, Quarry, Paving Road, Sassanid

\section{Introduction}

Persian Sassanid dynasty, named after the Great Persian Sassan and head of priests of Anahita Temple in Estakhr, ruled in Iran from the third to seventh century AD. This dynasty was established by Ardashir I in $226 \mathrm{AD}$ after defeating Artabanus V, the last monarch of Parthian dynasty. Sassanian period was the representative of Iranian national revolt against usurper Parthians politically and ideologically and aimed to revive the Achaemenid Empire. This aim was naturally reflected in the art of this period, which was an essentially court art continuously attempting to prove its relationship and link with the artistic tradition of Achaemenid period (Bousaily and Sheratov, 1997, 35). The most important monuments of this period include great majestic palaces of kings including Bishapur city, Sarvestan Palace and Firouzabad Palace. Bishapur is one of the most important
Sassanid cities located in Kazerun County. With $29^{\circ} 37^{\prime} 10^{\prime \prime} \mathrm{N}$ $51^{\circ} 39^{\prime} 15^{\prime \prime} \mathrm{E}$ coordinates, Kazerun County lies west of Fars Province at an altitude of 732 meters above sea level (Figure 1). The majority of syncline in which Kazerun Plain is located is covered by Quaternary sediments. It lies between two mountain ranges (the great north and south wall) as if shining in an open shell (Sheikh Alhokamayi, 2006: 19). Kazerun county is limited to Mamasani and Behbahan from north, to Shiraz from east and northeast, to Borazjan county and Bushehr from southwest and west and to Firouzabad from Southeast. Kazerun county has a surface area of 4119 square kilometers and is located in a plain 86 kilometers long and 90 kilometers wide. Morphologically, this county is located in a mountainous area surrounded by high mountains with northwest to southeast direction like other regions of Fars (Mozaffarian, 1994: 24). Geological structure of this county is related to the first (Cambrian) and third (Pliocene) geological time scale (Ziari, 2005. 21). Kazerun is situated in 
the path of Royal Road, which connected Persepolis to Susa in Achaemenid period and to Ctesiphon in Sassanid period (Mozaffarian 1994, 70).

The majority of studies have concerned the typical monuments of historical periods, especially Sassanid period. Systematic study of surface pottery of Bishapur city by M. Rajai in 2006, tracking survey of ancient Bishapur to Borazjan road by A. Ghasemi in 2007, study of Paleolithic sites in Parishan Lake basin by H. Vahdati Nasab in 2007, documentation study and identification of antiquities in Central Kazerun Plain by the author (M. H. Rezaei) in 2007, examination of settlement patterns of prehistoric sites of Kazerun Plain by the author (M. H. Rezaei) in 2010 and excavations of Tale Qaleh Nasir Abad by Nowruzi in 2014 are among the recent investigations in this region.
Following recent archaeological studies in Kazerun County, two stone quarries as well as a Paving Road related to Sassanid period were discovered in a mountainous region known as Kotal-e Dokhtar in east of Kazerun County. One of the quarries is located upstream to the ancient road and the other on a foothill not far from the ancient road. The remarkable point in the ancient stone quarry is that the vestiges of iron fasteners are visible on the sidelines of this quarry. This study deals with description, study and sampling of stones used for construction of macadam road as well as samples taken from Kotal-e Dokhtar 1 and 2 stone quarries based on laboratory methods. To achieve this goal, laboratory methods of studying thin sections of stones along with XRD and XRF will be applied.

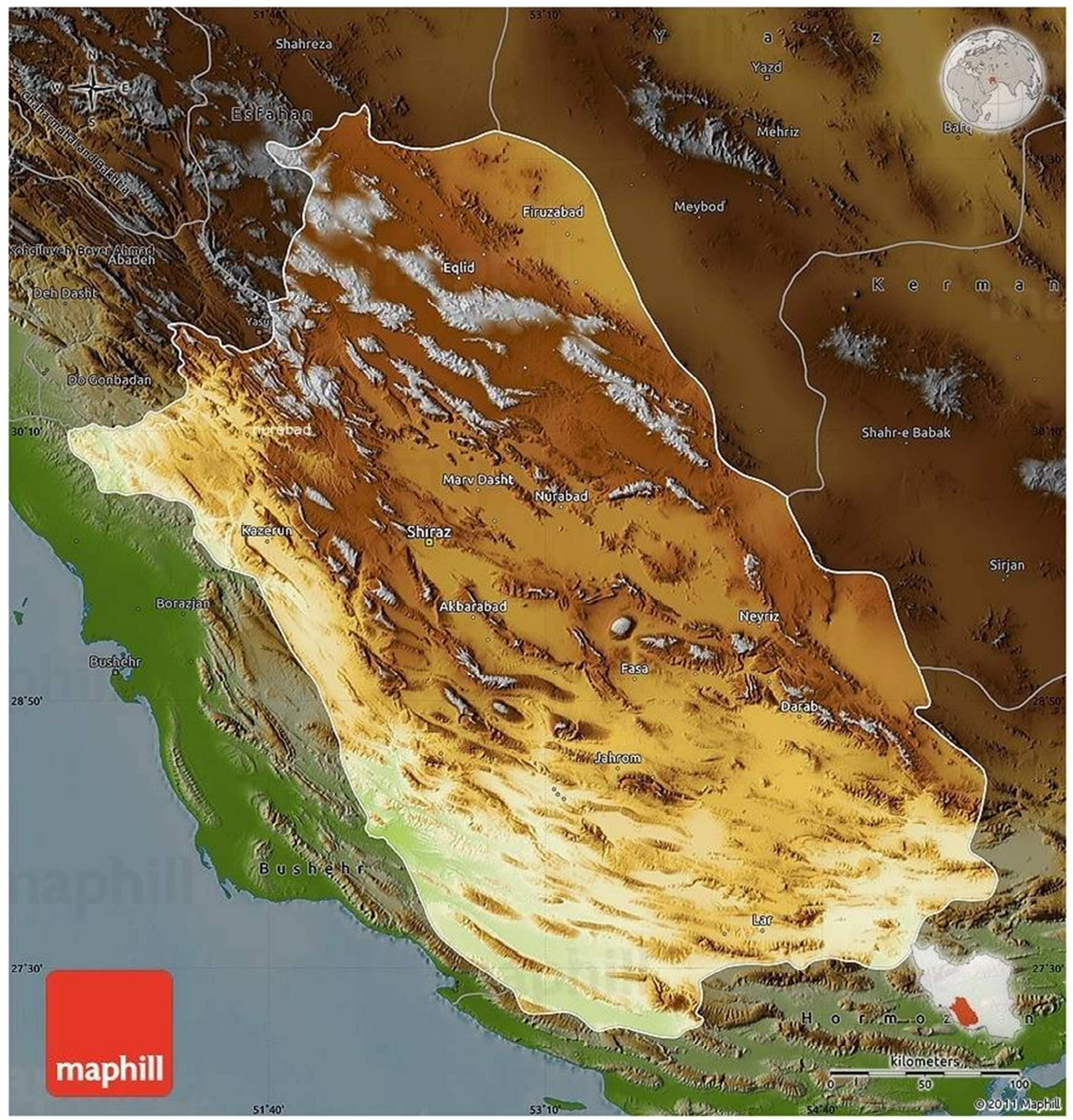

Figure 1. Location of Kazerun on map of Fars Province. 


\section{Geology of the Region}

Paleogeographic studies show that folded Zagros does not have similar geological features everywhere. With summarization of Motyei's work (1994), the following zones represent the majority of characteristics of folded Zagros. There is less folding in Fars Province and it has not lost its original state. The peaks and depressions are often located parallel to each other and there are no large rivers and broad valleys in this area due to rainfall. Eocene strata form huge masses in mountains of Fars Province. Zagros has been developed on schist, limestone and marl rocks and younger schist and marl Cretaceous formations with Paleocene fossils in Khuzestan, Lorestan and Fars regions (Figure 2). After a while, the precipitation environment has deepened and the formed limestone layers go together with marl and schist. Sedimentation has continued from Oligocene to Miocene in Zagros precipitation zone and has given rise to Asmari limestone formation.

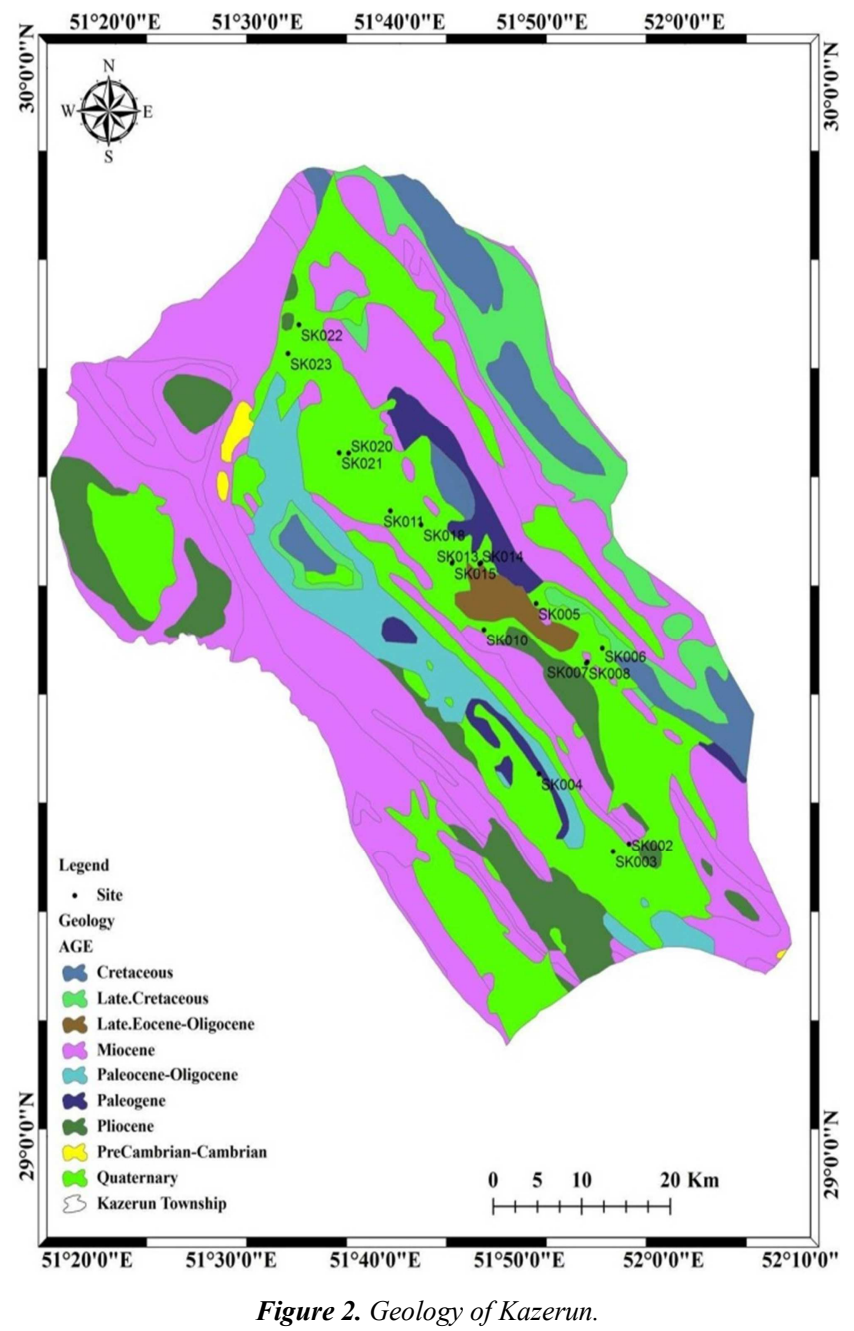

\section{Description and Introduction of Detected Stone Quarries and Paving Road and Presentation of Sample Analysis Results}

Sassanid stone quarry No. 1 of Barm Plain (Kotal-e Dokhtar): This stone quarry is located 15 kilometers east to the city of Kazerun. This quarry has $29^{\circ} 34.7^{\prime} 29^{\prime \prime} \mathrm{N}$ $51^{\circ} 47.56^{\prime} 55^{\prime \prime} \mathrm{E}$ coordinates with an altitude of 1055 meters above sea level. The quarry is 12 meters long and 10 meters wide with a surface area of 120 square meters and is an important quarry in the height of 300 meters relative to the level of plain and surrounding land (Figure 3 ). This quarry is located in the path of ancient Sassanid Paving Road and its stones have been probably used for construction of this road. Fissures of different sizes can be seen on the stones, including a fissure 1.32 meters long, $43 \mathrm{~cm}$ wide and 1 meter high as well as one $1.13 \mathrm{~m}$ long, $32 \mathrm{~cm}$ wide and $54 \mathrm{~cm}$ high (Figure 4). Molten metal can be observed on some stones, especially in crevices of stones (Figure 5).

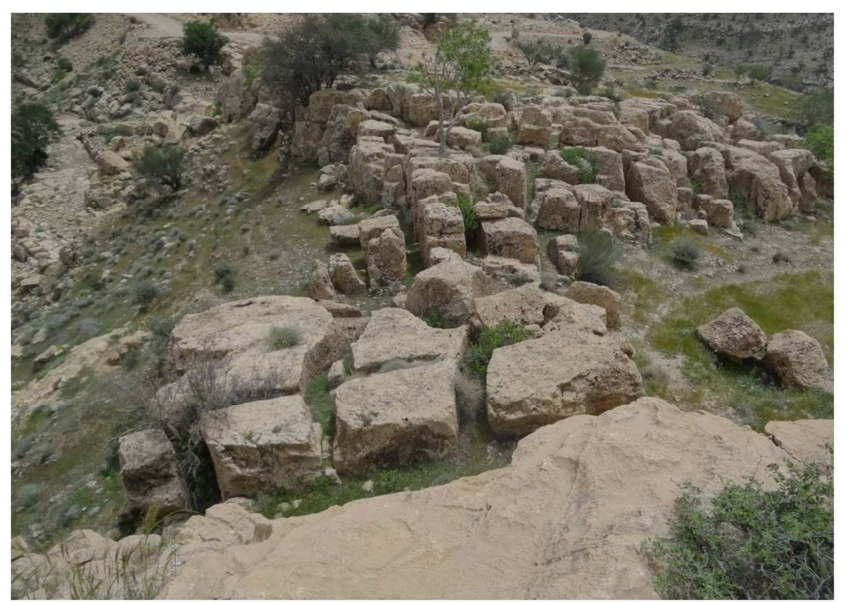

Figure 3. Stone quarry No.1 of Barm Plain (Kotal-e Dokhtar), view from west.

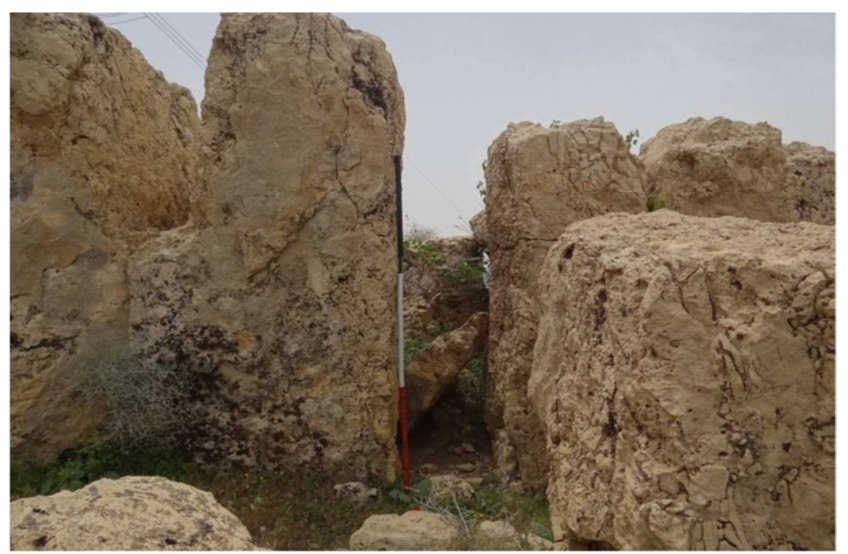

Figure 4. Fissure of quarry No.1 of Barm Plain (Kotal-e Dokhtar). 


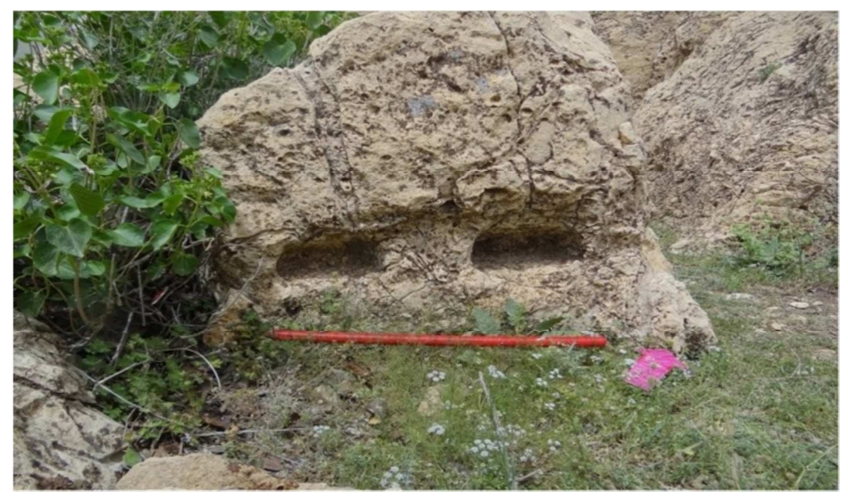

Figure 5. Metal fastener remnants of stone quarry of Barm Plain (Kotal-e Dokhtar).

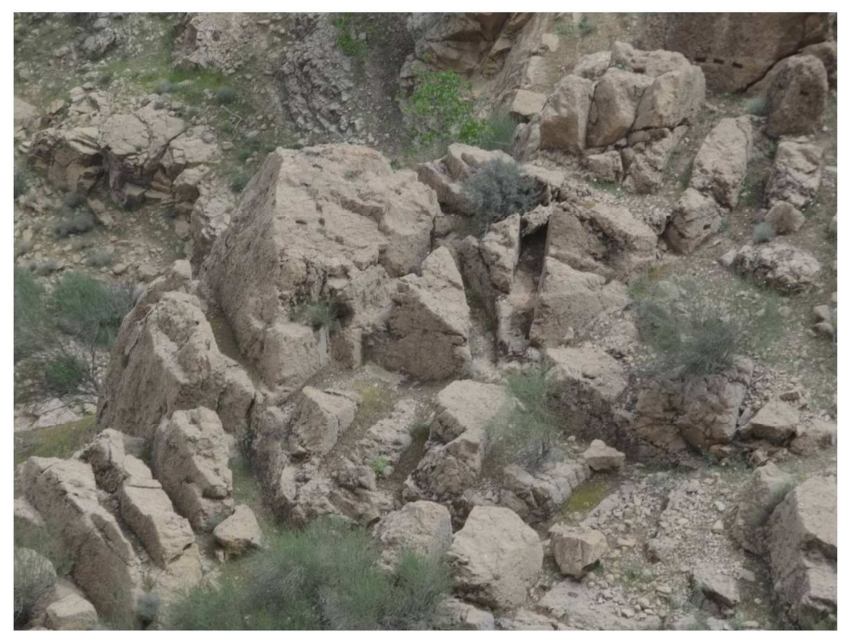

Figure 6. Stone quarry No. 2 of Barm Plain (Kotal-e Dokhtar), view from west.

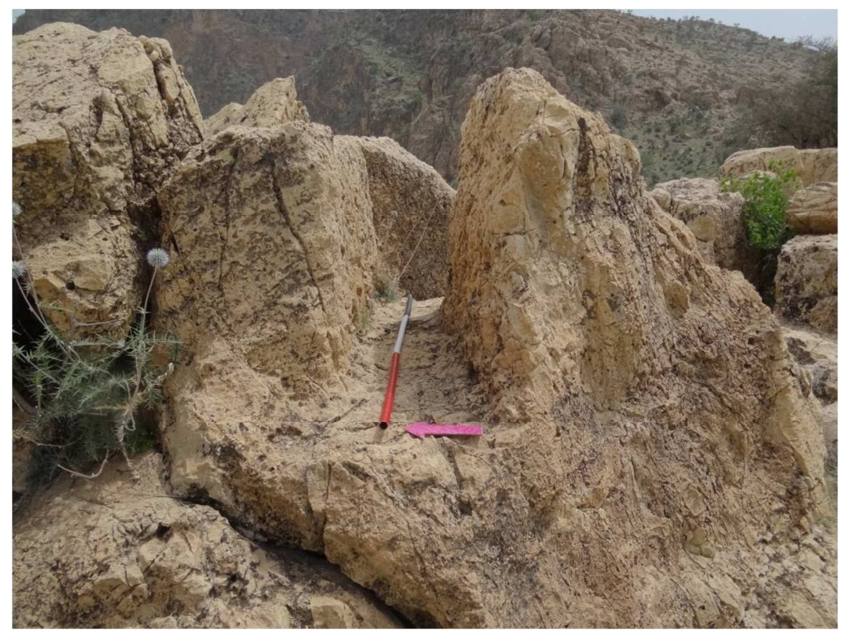

Figure 7. Cutting stone from quarry No. 2.

Sassanid stone quarry No. 2 of Barm Plain (Kotal-e Dokhtar): Quarry No. 2 of Barm Plain is located in a distance of 70 meters from the east of quarry No. 1 on the mountain slopes within the valley. This quarry has a length of 12 meters, width of 11 meters and surface area of $132 \mathrm{~m}$ with $29^{\circ} 34.7^{\prime} 74^{\prime \prime} \mathrm{N} 51^{\circ} 47^{\prime} 55.6^{\prime \prime} \mathrm{E}$ coordinates at an altitude of $1023 \mathrm{~m}$ above the sea level (Figure 6). The stones were cut from the middle or core of the stone. The color of stones in this quarry seems to be black to some extent. The stones were cut mainly by metal fasteners probably by laying wooden wedges within the stones, and the mark of fasteners can be seen on the stones of this quarry. The stones have been cut in different dimensions (length of 1.23 meters, width of $34 \mathrm{~cm}$ and height of 1 meter, another $2 \mathrm{~m}$ long, $42 \mathrm{~cm}$ wide and $1.122 \mathrm{~m} \mathrm{high}$ ) in order to remove the stone core since the core of stones is stronger and more resistant (Figure 7). The extracted stones are not smooth and may have been directly used for road construction because there is no sign of carving and polishing on the stones.

From these two stone quarries, two samples were taken for microscopic study and one sample was taken for XRF chemical analysis. This mining complex is probably located near a fault zone since quartz zones are observed in the form of a vein in microscopic sections, indicating a lag phase in the formation of silicified zones (Figures $8-10$ ).

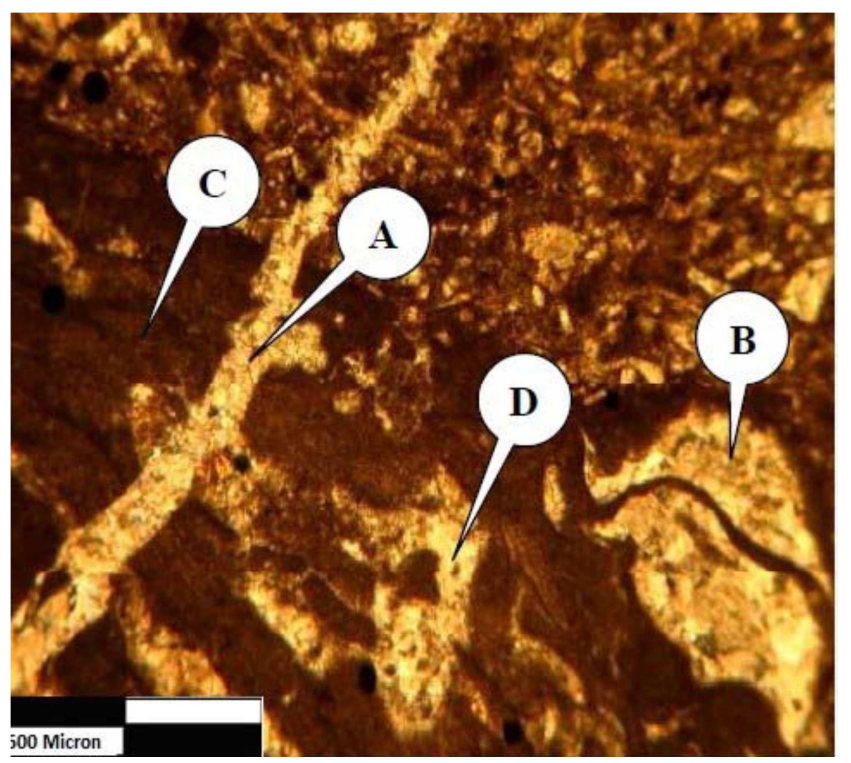

Figure 8. Composition of thin sections of Kotal-e Dokhtar quarry.

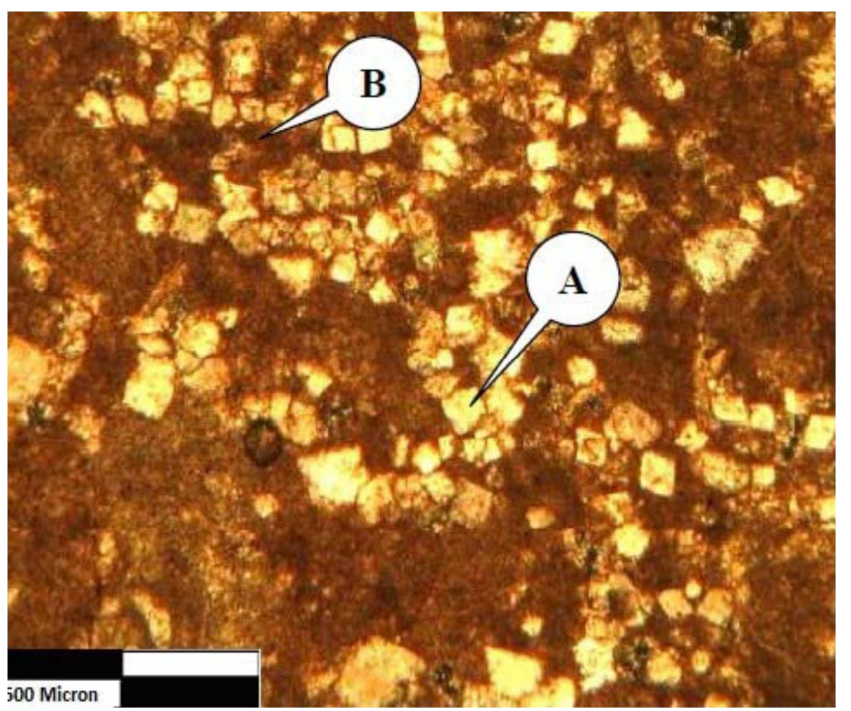

Figure 9. Composition of thin sections of Kotal-e Dokhtar quarry. 


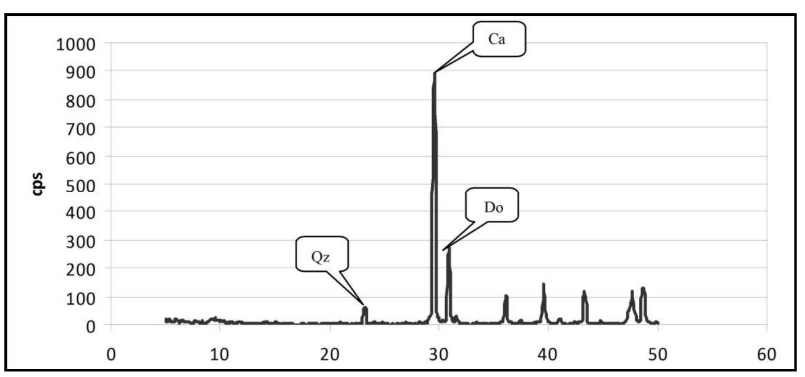

Figure 10. XRF test results on the samples taken from Kotal-e Dokhtar quarry 1 and 2 .

\section{Sassanid Paving Road of Kotal-e Dokhtar}

The ancient Paving Road of Kotal-e Dokhtar is located 15 $\mathrm{km}$ east of Kazerun County. This monument is located in $29^{\circ} 34.7^{\prime} 86^{\prime \prime} \mathrm{N} 51^{\circ} 47^{\prime} 56^{\prime \prime} \mathrm{E}$ coordinates at an altitude of 1024 $\mathrm{m}$ above the sea level (Figure 11). The length of this detected Paving Road is nearly $530 \mathrm{~m}$ in the mountainous part and approximately one kilometer in the plain, from which a few vestiges have remained in the form of a paved road that has disappeared over time due to erosion and human activities (Figure $12 \&$ 13). The ancient Paving Road of Kotal-e Dokhtar is $2.50 \mathrm{~cm}$ wide. In ancient times, this Royal Road connected Kazerun Plain to eastern and northern regions of Fars and had strategic and commercial importance. In the path of this road, some monuments have remained from Sassanid to Islamic period, including four square dome in the village of Haji Abad, figure of Timur and a cistern from the Islamic period and some ancient mounds, all indicating the existence and importance of this road in different historical periods. Stone, plaster and rubble have been used in construction of this road. The floor of the road has been paved with cobble stone and has been built from separate units (Figure 14). In the margin of road, a fence has been constructed from stone and plaster construction materials with built-in ditches to prevent the fall of man, horse and wagon. These ditches carried away the water from precipitation in winter.

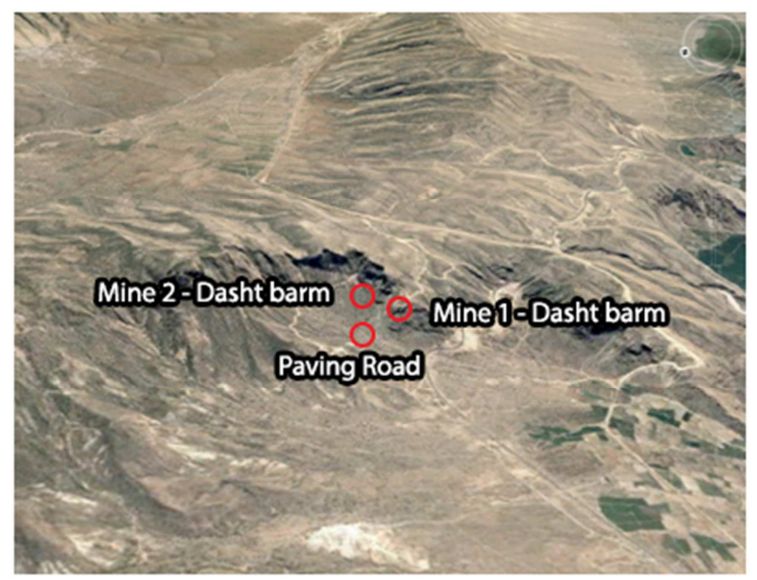

Figure 11. Paving Road of Kotal-e Dokhtar (view from north).

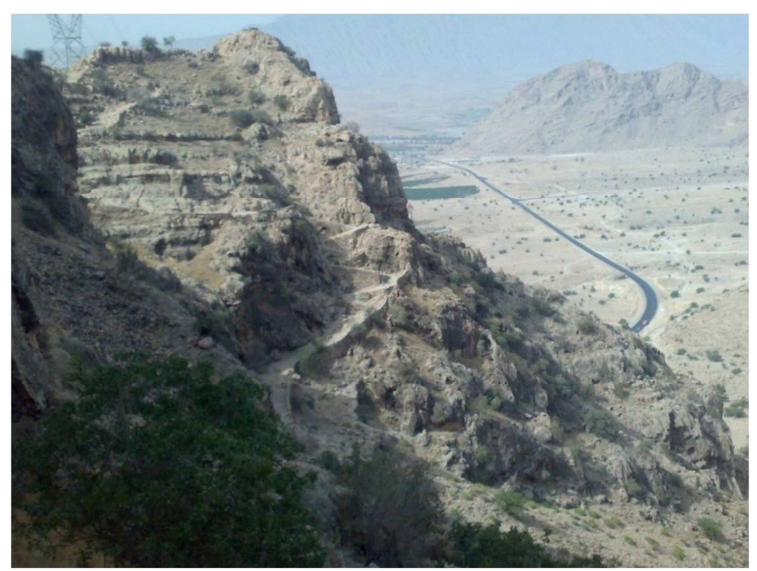

Figure 12. Paving Road of Kotal-e Dokhtar (view from north).

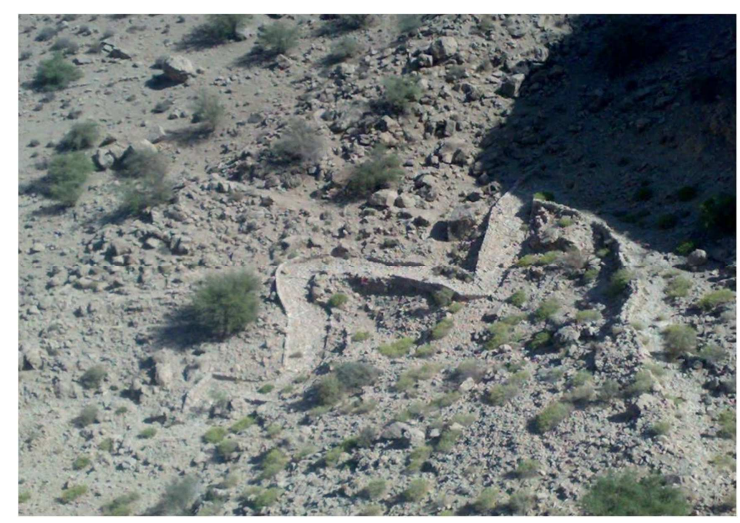

Figure 13. Paving Road of Kotal-e Dokhtar (view from west).

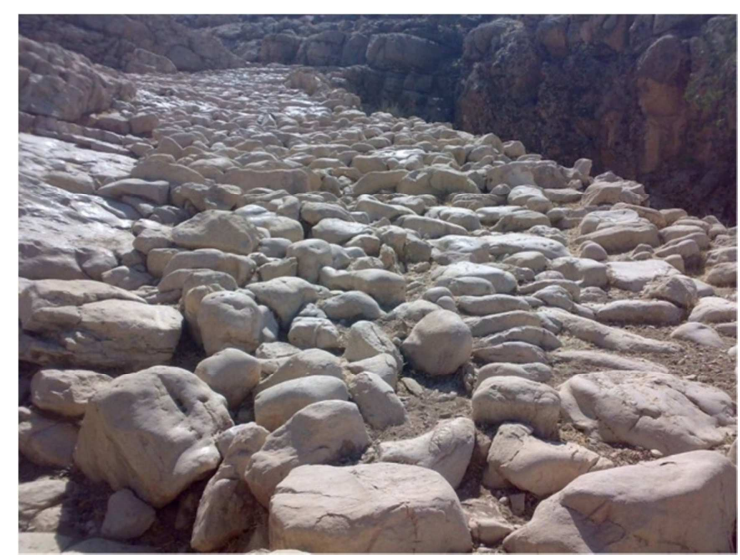

Figure 14. Paving Road of Kotal-e Dokhtar.

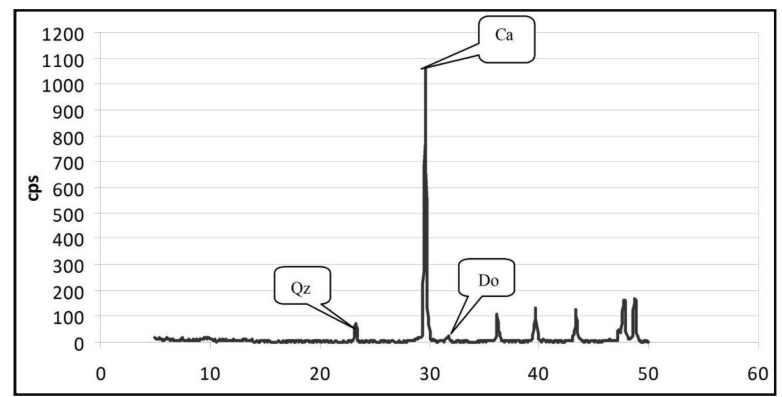

Figure 15. XRF test results on samples taken from Paving Road of Kotal-e Dokhtar. 
Due to specific conditions of this road, more samples were taken for analysis and microscopic study. XRF analysis showed that some of the stones of this Paving Road were of Kotal-e Dokhtar 1 and 2 quarries, and the stones from quarry were probably used for construction of the Paving Road (Figure 15).

\section{Discussion and Analysis}

In ancient times, important roads extended from the Iranian Plateau connecting East to West. The ancient highway (Royal Road) connected Perspolis and Susa through Elam, Kermanshah and Kurdistan to northern Iraq and eventually Sard, the capital of Lydia in Asia Minor. Despite the importance of this ancient highway, there has been little archaeological research about it. Herodotus, the Greek historian, in his fifth book describes the "Achaemenid Royal Road" as follows: this road goes through human settlements as well as secure regions and royal stations (excellent caravanserais) have been erected along this path from Lydia (modern west Anatolia) and Phrygia (inner Asia Minor) over 94 miles and a half. Management and maintenance of 2500kilometer-long "Royal Road" is a glory of Achaemenid Iran during the reign of Darius I. Although part of this great road existed before Darius I, it was the power of Darius I and his contemporary Iranians that turned trail fragments into the great Royal Road 2500 years ago. As is common today, the "Royal Road" also passed through outskirts to facilitate its maintenance and obviate the need to exert enormous power. The rebels and conquerors were not able to take advantage of it to reach their goals as it did not pass through the cities.

There are several techniques for the identification and classification of constituent materials and elements of archaeological data. Using advanced laboratory methods, broader dimensions of understanding and application of materials such as stones in prehistoric communities are enabled. The main purpose of identifying the ingredients of antiquities is exploring the origin and location of their production. This study deals with description, study and sampling of stones used for construction of Paving Road as well as samples taken from Kotal-e Dokhtar 1 and 2 stone quarries based on laboratory methods. To achieve this goal, laboratory methods of studying thin sections of stones along with XRD and XRF will be applied. In this study, the Paving Road and detected Kotal-e Dokhtar 1 and 2 quarries were first investigated and sampled and were then subject to a number of experiments. Microscopic analysis of thin sections and XRF were among the methods used for assessment. Experiments showed that the samples of Kotal-e Dokhtar 1 and 2 quarries had a similar composition and structure with some stones used to construct the Paving Road.

\section{Conclusion}

Kazerun County has been of particular importance in historical periods especially Achaemenid period due to location in the path of Royal Road as well as presence of Bishapur, an important capital of Sassanid period. The presence of small and large hills as well as various monuments is evidence for this claim. With regard to the importance of this region in Sassanid period, results of experiments on the stones of Sassanid monuments of Bishapur showing similar composition with stone quarries identified in this region and given the presence of hills and other Sassanid monuments such as square dome in a distance of 35 kilometers of this road and Kotal-e Dokhtar 1 and 2 quarries with historic city of Bishapur, the mentioned Paving Road has been constructed in Sassanid period.

\section{References}

[1] Aman Allahi, H., (2005). "The study of variety of stones used in the capital of Persepolis according to archaeological studies and results of petrographic studies". Journal of Archeology and interdisciplinary studies, first year, No. 2.

[2] Amiri, $M$ et al. (2012). Classification and typology of the Sassanid-Islamic pottery of Bishapur. Case study: the pottery of the ninth season of excavations. Journal of archaeological studies, Volume 4, No 1.

[3] Jafari, Seyed Mohiaddin (2005). "Macroscopic and microscopic study of the Achaemenid palace stone pillars and ancient quarry of Rahdar Puzeh Palangi". Archaeological reports, No. 4, Archeology Research Center, 267-268.

[4] Rashid Nejad, M., (2007). Experimental study of Achaemenid architecture of Hegmataneh site in Hamadan to realize the potential resources. Master's thesis, Tarbiat Modarres university.

[5] Ziari, Keramatollah, (2005). Urbanization and urban planning in Kazerun. First Edition, Tehran, Ganjeh honar Press.

[6] Sheikh Alhokamayi, E. (2006). Kazeruniyeh. The second book (a collection of articles on Kazerun). Kazrooniyeh publication.

[7] Sarfaraz, A. A., (2000). Manual of ancient works of Bishapur. First Edition. Mostafavi Press, Shiraz.

[8] Ghirshman, R, (2000). Bishapur. Translation by Asghar Karimi. Vol 1. Tehran, Cultural Heritage and tourism organization (Research Institute).

[9] Bousaily, M and Sheratov, U. (1997). Parthian and Sassanid Art. Translation by Jacob Azhand, Moula Press, First edition.

[10] Mozaffarian, M., (1994). Kazerun in view of culture. First edition, Navid Shiraz Press, Iran.

[11] Mehryar, M. (1999). Archaeological research and exploration background in Bishapur: Proceedings of the Second Congress of Iranian Urban History. Volume II. Tehran: Cultural Heritage Organization Press (Research institute).

[12] Nowruzi, R. (2005). Great Mosque of Bishapur (fifth season of the third round of archaeological studies of Bishapur). Proceedings of the second congress of young Iranian archaeologists. Tehran, Cultural Heritage and Tourism Organization (Office of Cultural Affairs). 